
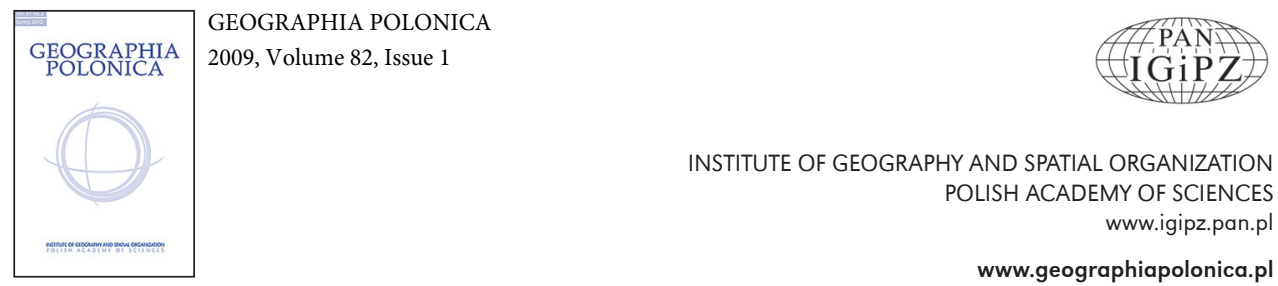

www.geographiapolonica.pl

\title{
VARIABILITY OF SELECTED EXTREME METEOROLOGICAL EVENTS IN POLAND
}

\author{
EWA ŁUPIKASZA, ZUZANNA BIELEC-BAৃKOWSKA, MAŁGORZATA FALARZ \\ Department of Climatology, Faculty of Earth Sciences, University of Silesia, \\ Będzińska 60, 41-200 Sosnowiec, Poland \\ E-mails: ewa.lupikasza@us.edu.pl; zuzanna.bakowska-bielec@us.edu.pl; malgorzata.falarz@us.edu.pl
}

\begin{abstract}
The principal aim of this paper is to analyze the trends of the multi-annual course of the selected characteristics of extreme precipitation, snow cover and atmospheric thunderstorms in the second half of the twentieth century in Poland. The results of these investigations show that in Poland it is only possible to determine a weak decreasing trend of extreme precipitation events in the S and especially in the SW part of the country. In northern Poland, opposite, although similarly weak, trends have also been observed. It is assumed that the most essential features of long-term changeability of extreme precipitation include a higher than average number of days with extremely high precipitation during the 1960s and 1970s, a distinctly lower frequency of such days during the 1950s, 1980s and in the first half of the 1990s. In Poland it is possible to distinguish four broad homogenous areas in terms of the long-term changes in the occurrence of extreme precipitation events. There is considerable regional differentiation when it comes to the occurrence of thunderstorms in Poland, and their long-term changeability does not show any clear trends. Only three stations have determined a weak increase in the number of thunderstorms during the last 120 years. In some stations, an increase in the number of days with thunderstorms during the winter seasons was also observed. There were no significant trends in extreme snow cover in Poland. The periods that contained large and small areas of extreme snow cover thickness occurred alternately. Since the winter season 1987/88, the area of extremely thin snow cover has remained at a relatively high level.
\end{abstract}

Key words: Extreme precipitation, thunderstorm, extreme snow cover, trends, Poland

\section{INTRODUCTION}

When discussing the issue of the influence of climate change on human living conditions, the problems concerning the occurrence and intensity of extreme climatic phenomena are often focussed upon. A special interest in extreme weather conditions arose due to their destructive influence on financial as well as incorporeal goods. In the last few years, alarming reports on extreme climatic events have been reported in the mass media much more often than in any previous period. These events have usually been linked to the intensification of the greenhouse effect, which has resulted in global warming. Are we really witnessing climate change that is happening more rapidly than in any other period of the past? According to the most recent IV IPCC Report, eleven of the last twelve years (1995 -2006) rank among the twelve warmest years in the instrumental record of global surface temperature (since $1850)$. The linear warming trend over the last 50 years $\left(0.13^{\circ} \mathrm{C}\right.$ per decade $)$ is nearly twice that of the last one hundred years. The total temperature increase from 1850-1899 to $2001-2005$ is $0.76^{\circ} \mathrm{C}$. Therefore, the snow cover area has decreased on average in both 
hemispheres; long-term trends from 1900 to 2005 have been observed in the amount of precipitation over many large regions (IPCC 2007). An answer to the above question, though difficult, seems to be much easier than an answer to the question concerning the drivers of climate change.

The results of the investigations that have been carried out to date show that in Poland there is a weak increasing trend of atmospheric precipitation totals, although it is not statistically significant (Kożuchowski 2004). Furthermore, a decreasing trend in the intensity of atmospheric precipitation has also been determined (Kożuchowski 2004), along with an increase in the number of days with precipitation in Poland (Niedźwiedź 2000a; Kożuchowski, Żmudzka 2003). Similar results concerning precipitation were obtained by Wibig (2006). The author, basing his analysis on trends recorded at five meteorological stations in Poland, also determined a decrease (which was not always statistically significant) in the number of days with precipitation exceeding the 75th and 90th percentile. The lack of statistically significant trends, or their presence only at single stations in Poland, confirm the investigations carried out on a larger spatial scale - that is, the whole of Europe (Klein-Tank et al. 2002; Klein-Tank and Können 2003). Other authors dealing with the problems of the occurrence of extreme precipitation in Poland include Kossowska-Cezak and Mrugała (1997), Cebulak (1992a, 1992b), Cebulak and Pyrc (2006), Kirschenstein (2006). Previous studies of extreme snow cover conditions have indicated a downward trend in the maximum snow cover depth in the southern part of Poland. However, the opposite tendency was observed in the north-eastern part of Poland (Falarz 2004). Moreover, a slightly negative, though usually statistically insignificant, trend was found for the characteristics of extremely abundant snow cover and the duration of seasonal snow cover (Falarz 2004, 2007). A contribution towards preventing the economic ravages of building disasters as a result of excessive snow depth was given by A. DeGaetano and D. Wilks (1999), who de- scribed a method that could be used to predict extreme snow loads on roofs.

The results of investigations concerning the occurrence of thunderstorms show their considerable spatial and time differentiation in Poland and in other parts of the world (Bielec-Backowska 2002; Brazdil 1998; Grabowska 2002; Kuleshov et al. 2002; Nosova 1989). It appears that even in the case of regions in close proximity to one another, the frequency of thunderstorm occurrence can be strongly differentiated. Even greater regional differentiation can be observed for short periods which contain a distinct increase or decrease in the number of thunderstorms (Changnon 1985, $1988,2001)$. In order to ascertain the reason for these changes, it was necessary to investigate the influence of atmospheric circulation types or indices and the tracks of cyclone movements on the frequency of thunderstorms (Boryczka, Stopa-Boryczka 2002; Changnon 1985; Nosova 1989).

Analysis of the variations and trends in extreme climatic events is crucial in order to forecast their further occurrence. The main aim of this work is to determine the general trends in the occurrence of extreme events concerning atmospheric precipitation, thunderstorm and snow conditions in Poland in the second half of the twentieth century.

\section{METHODS AND DATA}

Precipitation. Daily precipitation totals for the period 1951-2000 at selected meteorological stations located in Poland were used in analyses of extreme precipitation events (Fig. 1). Referring to the classification of extreme meteorological and hydrological events in Central Europe (Niedźwiedź et al. 2006), an extreme event is defined as a daily precipitation total exceeding the value of the 90 th percentile. The value of the 90th percentile was determined individually for each of the meteorological stations studied, based on daily precipitation totals in the period 1961-1990, taking into account days with precipitation $>1 \mathrm{~mm}$ 


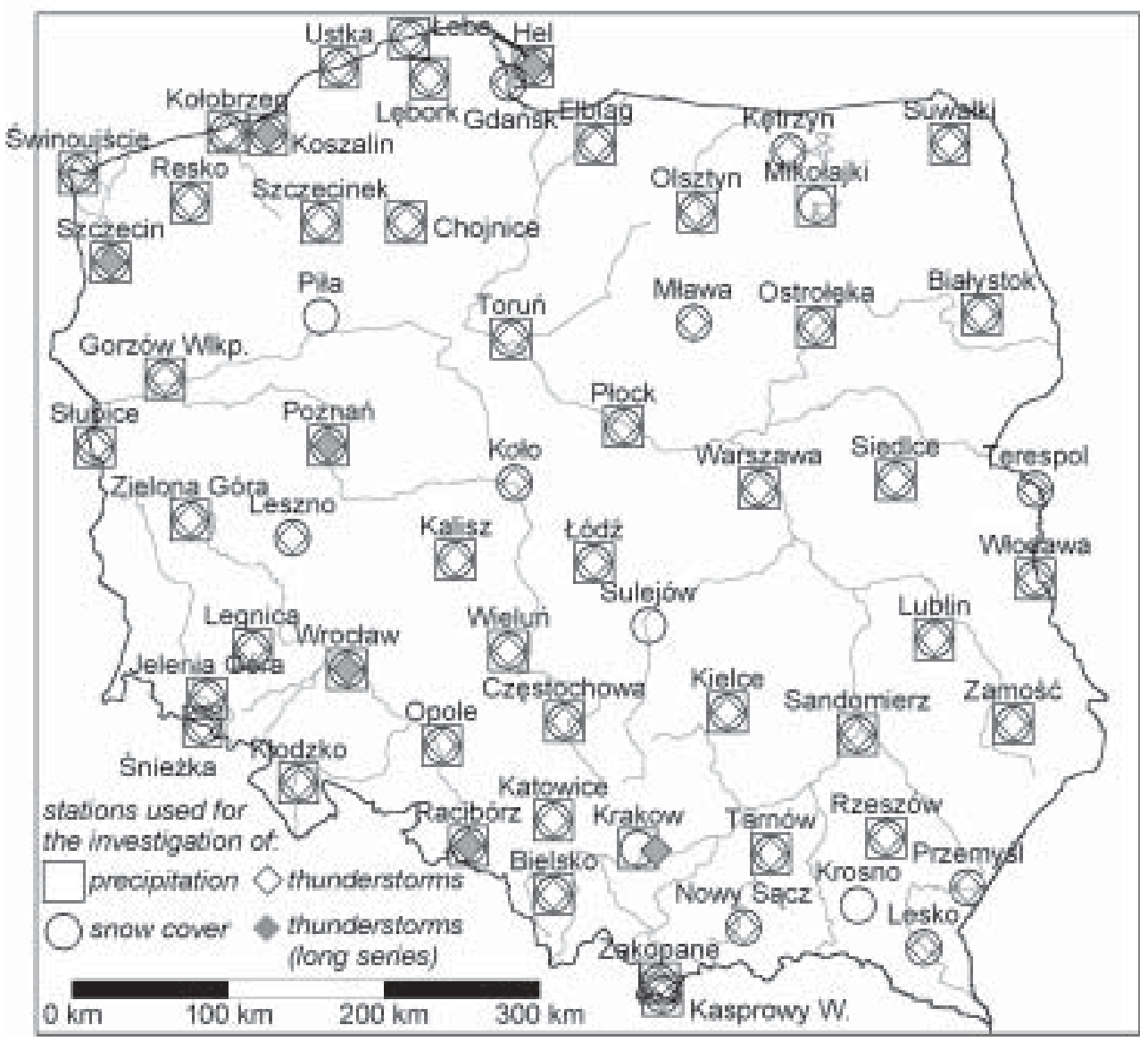

Figure 1. Location of meteorological stations used in the study.

(Klein-Tank et al. 2002). The following problems were investigated: 1) while using the Mann-Kendall method (the details of the theory can be found in Gilbert (1987)), the existence of general trends in the occurrence of extreme precipitation over the whole period (1951-2000) under analysis and in the 30-year moving periods were studied, 2) the long-term variability of the given indices was analysed based on their arithmetically averaged values for Poland, 3) when applying cluster analysis of the $\mathrm{k}$-means method, those regions of similar long-term variability in the number of days with extreme precipitation ( $>90$ th) percentile were distinguished.
Thunderstorms. The basis for the research concerning the occurrence of thunderstorm events were meteorological observations from:

- 7 stations (Hel, Szczecin, Koszalin, Poznań, Wrocław, Racibórz, Kraków) for the period 1885-2000; these contained, with the exception of Kraków, some gaps of several years caused by the First and Second World Wars;

- 56 meteorological stations for the period 1949-1998 (Fig. 1).

A day with a thunderstorm, including those which were close and distant, has become the basic index that shows the occurrence of thunderstorms. 
Snow cover. Seasonal data on the maximum snow cover depth in 60 meteorological stations in Poland for the period 1954/552000/01 were analysed (Fig. 1). Snow cover series for 6 of the 60 meteorological stations were incomplete. The missing seasonal data for one winter season, mainly for the first or the last winter of the investigated period, were filled in using the data of 1-3 neighbouring stations located in those areas that had similar snow conditions. The quality of the observations was controlled and corrected. The homogeneity of the seasonal snow cover data was controlled with the Standard Normal Homogeneity Test (Alexandersson 1986). Three inhomogeneous series (Lublin, Mława, Mikołajki) were then adjusted.

Winter seasons of extremely thin (thick) snow cover were defined as winters with a maximum seasonal snow cover depth of below $10 \%$ (above $90 \%$ ) of the empirical probability. The spatial distribution of the above mentioned limit values was analysed. The variability of the extent of the snow cover with extremely thin and extremely thick snow cover depth in the period 1954/552000/01 was investigated. It was assumed that each meteorological station represents $1 / 60$ of the area of Poland.

Changes in precipitation. The trend parameters were calculated for the following three characteristics of extreme precipitation events: number of days with extreme precipitation ( $>90$ th percentile), precipitation totals during days with extreme precipitation $(>90$ th percentile), and the share of extreme precipitation ( $>90$ th percentile) in the yearly total. No statistically significant linear tendencies in extreme precipitation in Poland in the second half of the twentieth century (19512000) were observed. Significant trends were observed only at individual meteorological stations (from 5 to 2 stations depending on the index) (Table 1). It should be added that the mountain meteorological station at Śnieżka (in the Sudeten Mountains) was the only one in which a statistically significant decrease in the values of all the considered characteristics of extreme precipitation in the period 1951-2000 was observed. In the NW part of Poland, near Kołobrzeg, the opposite tendencies were observed (Table 1).

To sum up, the analysis of extreme precipitation events in the second half of the twentieth century shows only a weak decrease in the S and especially SW part of Poland. Opposite, but similarly weak trends were observed in N Poland.

When applying a trend method, it should be remembered that the results strongly depend on the value of the element studied both at the beginning and at the end of the period under investigation. As a result, the determined value and direction of trends is only appropriate for the analysed time interval. Thus, in order to supplement and determine more precisely a possible trend in the course of extreme precipitation events, data for subsequent consecutive 30-year periods were also analysed.

The analysis of trends in consecutive 30 -year periods was carried out on the basis of arithmetically averaged values of the individual characteristics of precipitation extremes for Poland. This approach made it possible to distinguish a particular period which began in the mid-1960s and lasted until the early 1990s, which was characterized by a statistically significant negative trend of all three characteristics of extreme precipitation events in Poland (Table 2). Taking into account the results of the individual stations, it was discovered that the strongest, decreasing trends could be seen in precipitation totals during days with extreme precipitation, and they occurred during three consecutive 30 -year periods, starting from 1964-93. In these years, statistically significant trends occurred in the case of ca. $50 \%$ of the investigated stations located mainly in southern and also partly in eastern Poland (Fig. 2).

The period of decreasing trends of extreme precipitation events in Poland is clearly visible in the long-term course of arithmetically averaged values of the number of days with precipitation exceeding a threshold value of the 90th percentile (Fig. 3A). The course of other indices (that is, precipitation total during extremely rainy days and the share of this value in an- 
Table 1 Tendencies in extreme precipitation $\left(>90^{\text {th }}\right.$ percentile $)$ in the period 1951-2000 in Poland.

\begin{tabular}{|c|c|c|c|c|c|c|}
\hline & $\begin{array}{r}\text { number of } \\
\text { precipitation } \geq 9\end{array}$ & $\begin{array}{l}\text { ays with } \\
\text { th }^{\text {th }} \text { percentile }\end{array}$ & $\begin{array}{r}\text { precipitation tota } \\
\text { precipitation } \geq 9\end{array}$ & $\begin{array}{l}\text { at days with } \\
\text { th percentile }\end{array}$ & $\begin{array}{l}\text { share of precipi } \\
\text { days with preci } \\
\text { percentile in }\end{array}$ & $\begin{array}{l}\text { tion total at } \\
\text { tation } \geq 90^{\text {th }} \\
\text { nual total }\end{array}$ \\
\hline & $\begin{array}{l}\text { change/10years } \\
\text { [No. of days] }\end{array}$ & $\begin{array}{c}\text { statistical } \\
\text { significance }\end{array}$ & $\begin{array}{c}\text { change/10years } \\
{[\mathrm{mm}]}\end{array}$ & $\begin{array}{c}\text { statistical } \\
\text { significance }\end{array}$ & change/10years & $\begin{array}{c}\text { statistical } \\
\text { significance }\end{array}$ \\
\hline$\overline{\text { Kołobrzeg }}$ & $\frac{\mid \text { [No. O1 days }}{0.6}$ & $*$ & {$[14 \mathrm{I}]$} & $\frac{d r g i m i c a n c e}{+}$ & $\begin{array}{c}|70|] \\
1.5\end{array}$ & - \\
\hline Koszalin & 0.3 & - & 4.5 & - & -0.4 & - \\
\hline Ustka & 0.2 & - & 3.2 & - & 0.2 & - \\
\hline Łeba & -0.1 & - & -1.9 & - & 0.4 & - \\
\hline Lębork & 0.0 & - & 2.3 & - & -0.4 & - \\
\hline Hel & 0.4 & - & 6.3 & - & 0.5 & - \\
\hline Elblag & 0.0 & - & 2.7 & - & -0.4 & - \\
\hline Suwałki & 0.1 & - & -4.7 & - & -1.3 & - \\
\hline Świnoujście & 0.2 & - & 1.2 & - & -0.2 & - \\
\hline Szczecin & -0.1 & - & 8.3 & - & 0.5 & - \\
\hline Resko & -0.1 & - & 10.8 & - & 0.4 & - \\
\hline Szczecinek & -0.3 & - & 2.9 & - & -0.7 & - \\
\hline Chojnice & -0.2 & - & $-6,1$ & - & -1.8 & * \\
\hline Toruń & 0.0 & - & 10.1 & - & 1.1 & - \\
\hline Olsztyn & 0.1 & - & -1.6 & - & -1.3 & - \\
\hline Ostrołeka & 0.2 & - & 4.8 & - & -0.4 & - \\
\hline Białystok & -0.2 & - & 0.4 & - & 0.2 & - \\
\hline Gorzów Wlk. & 0.5 & + & 1.4 & - & $0 ., 2$ & - \\
\hline Stubice & -0.2 & - & 1.2 & - & $-0 ., 4$ & - \\
\hline Poznań & 0.2 & - & 9.1 & - & 0.3 & - \\
\hline Płock & -0.5 & - & -1.2 & - & 0.0 & - \\
\hline Warszawa & 0.2 & - & 5.9 & - & 0.4 & - \\
\hline Siedlce & -0.2 & - & -2.0 & - & -0.3 & - \\
\hline Zielona Góra & -0.2 & - & -8.4 & - & -1.2 & - \\
\hline Legnica & -0.1 & - & -2.4 & - & 0.1 & - \\
\hline Wrocław & 0.1 & - & -4.8 & - & -0.5 & - \\
\hline Kalisz & 0.2 & - & -3.5 & - & -0.4 & - \\
\hline Wieluń & 0.2 & - & 2.7 & - & 0.3 & - \\
\hline Łódź & 0.1 & - & -1.0 & - & -0.6 & - \\
\hline Lublin & -0.1 & - & 4.6 & - & 0.4 & - \\
\hline Włodawa & -0.3 & + & -3.8 & - & -0.2 & - \\
\hline Jelenia Góra & 0.1 & - & -12.9 & - & -1.9 & * \\
\hline Śnieżka & -0.9 & * & -67.7 & ** & -2.7 & ** \\
\hline Kłodzko & 0.1 & - & -7.7 & - & -1.0 & - \\
\hline Opole & 0.1 & - & 8.1 & - & 0.9 & - \\
\hline Racibórz & -0.4 & + & -6.4 & - & -0.2 & - \\
\hline Częstochowa & -0.2 & - & 2.7 & - & 0.4 & - \\
\hline Katowice & 0.0 & - & 5.4 & - & 0.4 & - \\
\hline Kraków & 0.2 & - & 0.8 & - & -0.3 & - \\
\hline Kielce & -0.1 & - & 2.9 & - & 0.0 & - \\
\hline Tarnów & 0.3 & - & 7.2 & - & 0.4 & - \\
\hline Rzeszów & 0.3 & - & 2.9 & - & -0.2 & - \\
\hline Sandomierz & 0.1 & - & -3.1 & - & -0.3 & - \\
\hline Zamość & 0.0 & - & -0.3 & - & 0.0 & - \\
\hline Bielsko Biała & -0.4 & - & -2.6 & - & 0.2 & - \\
\hline Zakopane & -0.6 & - & -7.1 & - & -0.6 & - \\
\hline $\begin{array}{l}\text { Kasprowy } \\
\text { Wierch }\end{array}$ & -0.1 & - & 25.9 & - & 0.8 & - \\
\hline
\end{tabular}

Significance level: “+” significant at 0.1 ; “*” significant at 0.05 ; “**” significant at 0.01 ; “***” significant at 0.001 ; “-” not significant

nual precipitation), shows similar features of long-term variability. The most significant of these is the above average number of days with extreme high precipitation in the 1960s, and 1970s, and the rather lower frequency of the occurrence of such days in the $1950 \mathrm{~s}, 1980 \mathrm{~s}$ and in the early 1990s. It is worth noting that there is an increasing trend since the 1990s. Extreme precipitation events often represent phenomena which 
Table 2. Tendencies in extreme precipitation $\left(>90^{\text {th }}\right.$ percentile) in 30 -year moving periods within the 19512000 period in Poland. Tendencies were counted on the basis of Polish time series of extreme precipitation indices. Polish time series of indices were obtained by arithmetic averaging of stations' time series.

\begin{tabular}{|c|c|c|c|c|c|c|}
\hline \multirow{2}{*}{$\begin{array}{l}30 \text {-year } \\
\text { moving } \\
\text { periods }\end{array}$} & \multicolumn{2}{|c|}{$\begin{array}{l}\text { number of days with } \\
\text { precipitation } \geq 90^{\text {th }} \text { percentile }\end{array}$} & \multicolumn{2}{|c|}{$\begin{array}{l}\text { precipitation total at days } \\
\text { with precipitation } \geq 90^{\text {th }} \\
\text { percentile }\end{array}$} & \multicolumn{2}{|c|}{$\begin{array}{l}\text { share of precipitation total at } \\
\text { days with precipitation } \geq 90^{\text {th }} \\
\text { percentile in annual total }\end{array}$} \\
\hline & $\begin{array}{c}\text { change/10years } \\
{[\text { No of days] }}\end{array}$ & $\begin{array}{c}\text { statistical } \\
\text { significance }\end{array}$ & $\begin{array}{c}\text { change/10years } \\
{[\mathrm{mm}]}\end{array}$ & $\begin{array}{c}\text { statistical } \\
\text { significance }\end{array}$ & $\begin{array}{c}\text { change/10years } \\
{[\%]}\end{array}$ & $\begin{array}{c}\text { statistical } \\
\text { significance }\end{array}$ \\
\hline $1951-1980$ & 0.7 & - & 16.7 & - & 1.4 & - \\
\hline $1952-1981$ & 0.6 & - & 13.1 & - & 1.0 & - \\
\hline 1953-1982 & 0.4 & - & 6.9 & - & 0.0 & - \\
\hline 1954-1983 & 0.0 & - & -2.7 & - & -0.5 & - \\
\hline 1955-1984 & -0.4 & - & -10.4 & - & -0.9 & - \\
\hline 1956-1985 & -0.5 & - & -11.1 & - & -1.0 & - \\
\hline $1957-1986$ & -0.5 & - & -11.4 & - & -1.1 & - \\
\hline $1958-1987$ & -0.4 & - & -10.8 & - & -1.0 & - \\
\hline $1959-1988$ & -0.5 & - & -10.6 & - & -1.2 & - \\
\hline 1960-1989 & -0.8 & + & -15.1 & + & -1.2 & - \\
\hline $1961-1990$ & -0.7 & + & -13.9 & + & -1.2 & + \\
\hline $1962-1991$ & -0.8 & * & -16.1 & $*$ & -1.5 & * \\
\hline 1963-1992 & -1.0 & $*$ & -20.4 & ** & -2.0 & ** \\
\hline 1964-1993 & -1.1 & ** & -28.6 & $* *$ & -2.5 & ** \\
\hline $1965-1994$ & -1.2 & ** & -30.1 & $* *$ & -2.8 & $* * *$ \\
\hline 1966-1995 & -1.1 & ** & -28.6 & $* *$ & -2.6 & $* *$ \\
\hline $1967-1996$ & -0.8 & $*$ & -18.9 & * & -2.0 & * \\
\hline 1968-1997 & -0.5 & - & -13.1 & - & -1.5 & - \\
\hline 1969-1998 & -0.2 & - & -8.6 & - & -1.0 & - \\
\hline 1970-1999 & -0.4 & - & -11.6 & - & -0.8 & - \\
\hline $1971-2000$ & 0.0 & - & -3.5 & - & -0.5 & - \\
\hline
\end{tabular}

Significance level: “+” significant at $0.1 ;$ “*” significant at 0.05 ; “**” significant at 0.01 ; “***” significant at 0.001 ; "“” not significant
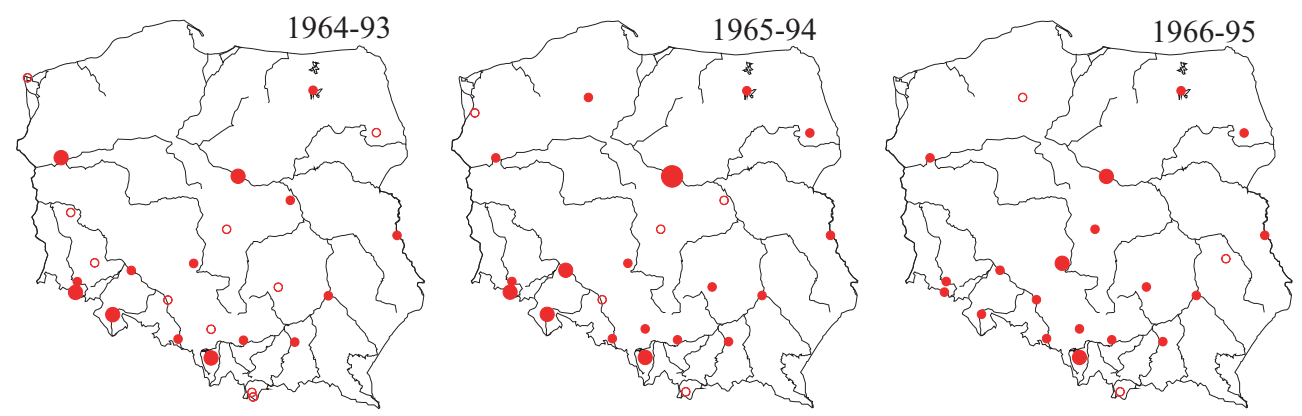

Figure 2. Tendencies in extreme precipitation totals $\left(>90^{\text {th }}\right.$ percentile) for selected 30 -year moving periods in Poland. Red dots mean a decreasing trend, statistically significant at: $\circ 0.1 ; \bullet 0.05 ; \bullet 0.01$; $\bullet$ 0,001 . Blue dots mean an increasing trend, statistically significant at: $\circ 0.1 ; \bullet 0.05 ; \bullet 0.01 ; \bullet 0.001$.

occur locally. Therefore, the conclusion that the long-term variability of the investigated indices of precipitation extremes was characterized by relatively small spatial changeability in the broad areas of Poland appears to be interesting. It was proved by the statistically significant correlation coefficients (over 0.6) between the area averaged values of extreme precipitation indices and their values at individual stations (Fig. 3B).

The best results of regionalisation using cluster analyse of the k-means method were obtained after they were divided into 6 clusters (Fig. 4). Both clusters 1 and 2 consist of one station each (mountain stations). As a result, it was stated that in Poland there are 

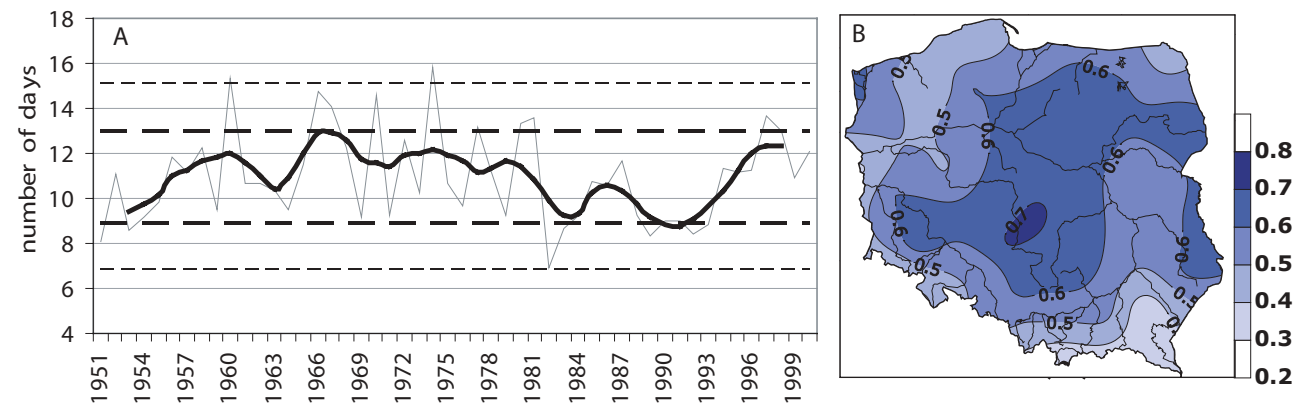

Figure 3. Long-term variability of the number of days with precipitation $>90^{\text {th }}$ percentile in Poland. (A - Polish time series obtained by arithmetic averaging of stations' time series, B - spatial distribution of correlation coefficients between Polish time series of investigated index and its values at each meteorological station).

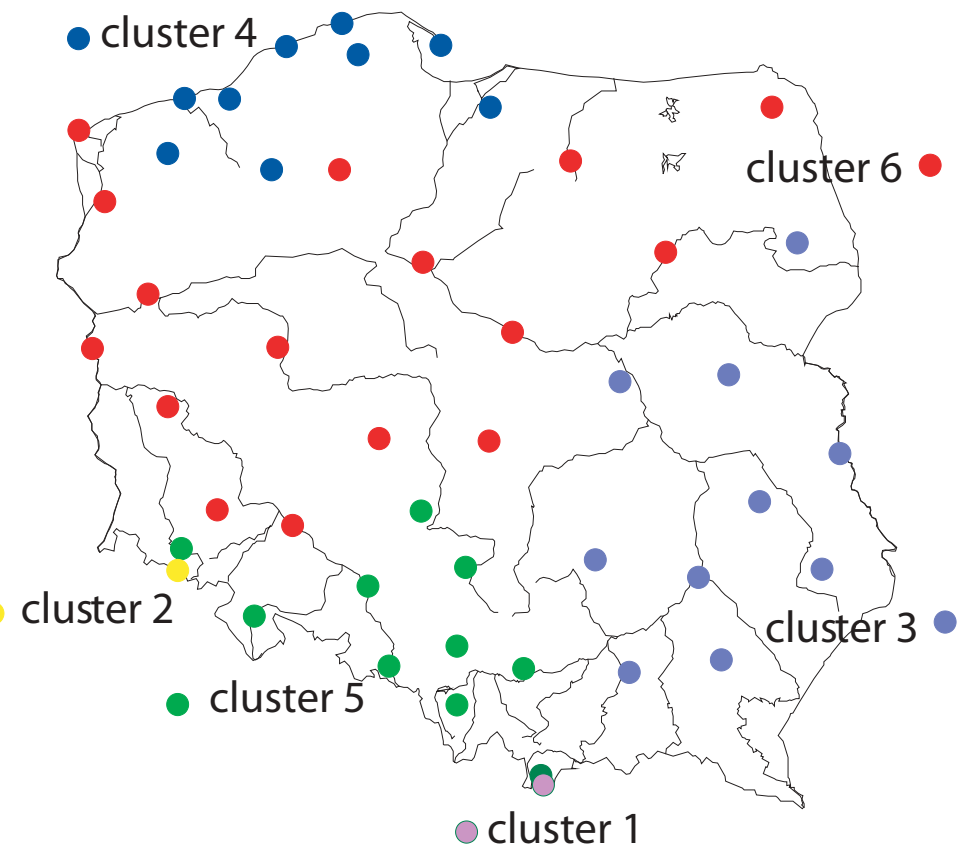

Figure 4. Regions of coherent long-term variability in the number of days with precipitation $>90^{\text {th }}$ percentile in Poland.

four broad areas of different size which are homogenous in terms of their long-term variability of the occurrence of extreme precipitation events (Fig. 4). The obtained regional division is consistent with the spatial distribution of correlation coefficients between the area averaged values of precipitation indices for Poland and their values at individual sta- tions. The largest area of similar long-term variability of extreme high precipitation encompasses the central part of Poland (cluster 6/ region 6) (Fig. 4). Region 6 is characterized by the smallest range of variability of days with precipitation $>90$ th percentile. High average number of days with extreme precipitation is noted in the region located in 


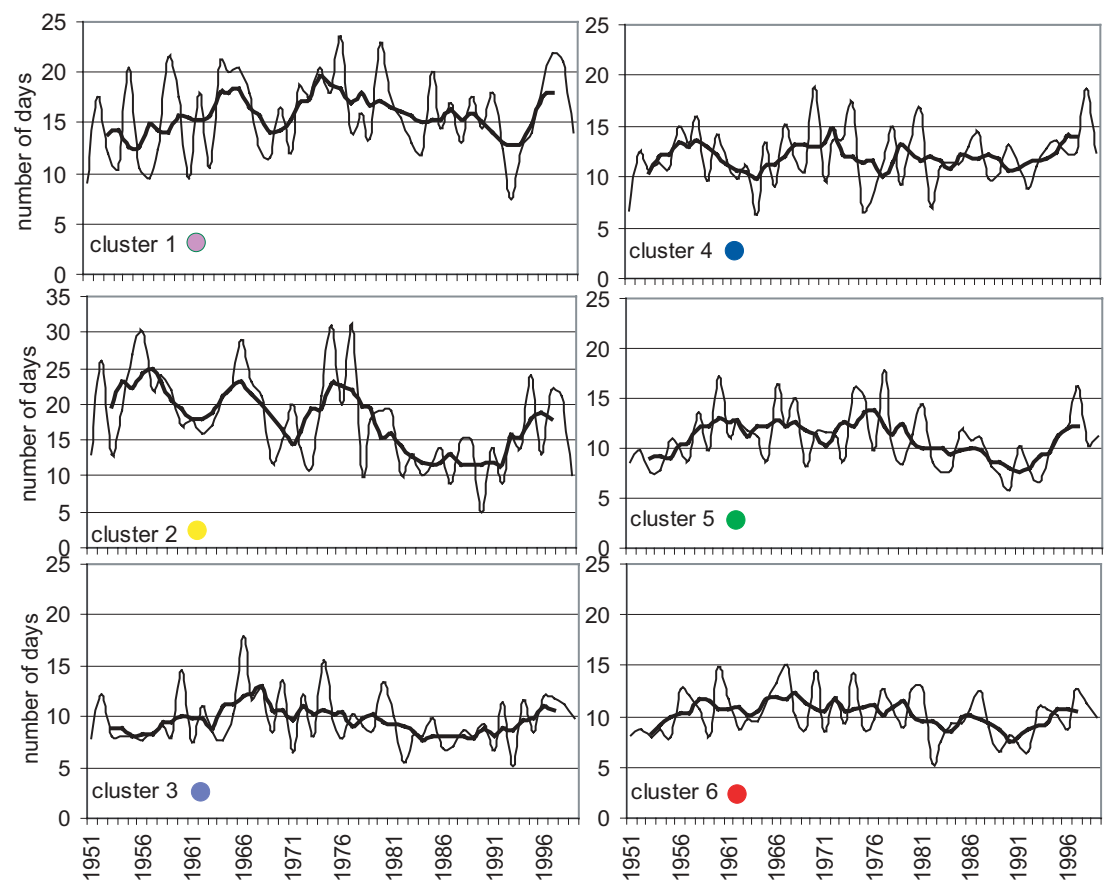

Figure 5. Regional time series of the number of days with precipitation $>90^{\text {th }}$ percentile. Regional time series were obtained by arithmetic averaging of stations' series counted among the same cluster.

the north-western part of Poland (cluster 4/ region 4). Moreover, it should be underlined that in mountainous areas the long-term variability of precipitation extremes is considerably different than those of other areas. Regional time series of the number of days with extreme precipitation (>90th percentile) and their numerical characteristics, including average, maximum and minimum values, are presented in Fig. 5 and Table 3.

The preliminary results on the relationship between atmospheric circulation and the occurrence of extreme precipitation events show that the spatial configurations of the distinguished regions may be associated with the origin of this type of events.

Changes in thunderstorms. The obtained results show that in Poland there are about 24 stormy days per year on average. This number oscillates between 15 and 33 per year depending on the region and it increases from the north-west to the south-east
(Bielec-Bakowska 2002). The smallest annual number of days with a thunderstorm usually oscillates between 10 and 14 days in a year (39.3\% of all the stations). The smallest values in the index are noted on the Baltic Seacoast - 4 days in 1976 in Ustka. The largest annual number of days with a thunderstorm usually occurred in the range from 30 to 39 days (66.1\% stations) and the largest number of such days was noted at Kasprowy Wierch - 54 days with a thunderstorm in 1963 (Fig. 6A-C). A spatial distribution of $10 \%$ quantile of the annual number of days with thunderstorms shows that on the seacoast the least occurring years were those with more than 23-25 thunderstorm days, whereas in south-eastern Poland there were years where over 35 and even up to 39 days with thunderstorms were noted (Fig. 6E). In the periods where in a given station or a region the largest number of stormy days was noted, this number exceeded mean annual 
Table 3. Average, maximum and minimum number of days with precipitation $>90^{\text {th }}$ percentile for clusters of similar long-term variability of days with precipitation $>90^{\text {th }}$ percentile.

\begin{tabular}{ccccccc}
\hline $\begin{array}{c}\text { numerical } \\
\text { characteristic }\end{array}$ & cluster 1 & cluster 2 & cluster 3 & cluster 4 & cluster 5 & cluster 6 \\
\hline Average & 15.7 & 17.7 & 9.6 & 12.0 & 10.9 & 10.2 \\
Maximum & 23.5 & 31.0 & 18.0 & 18.9 & 17.8 & 15.0 \\
Minimum & 7.5 & 5.0 & 5.1 & 6.2 & 5.9 & 5.3 \\
$\begin{array}{c}\text { Range of } \\
\text { variability }\end{array}$ & 16.0 & 26.0 & 12.9 & 12.7 & 11.9 & 9.7 \\
\hline
\end{tabular}

Significance level: "+” significant at 0.1 ; “*” significant at 0.05 ; “**” significant at 0.01 ; “***” significant at 0.001 ; "-” not significant
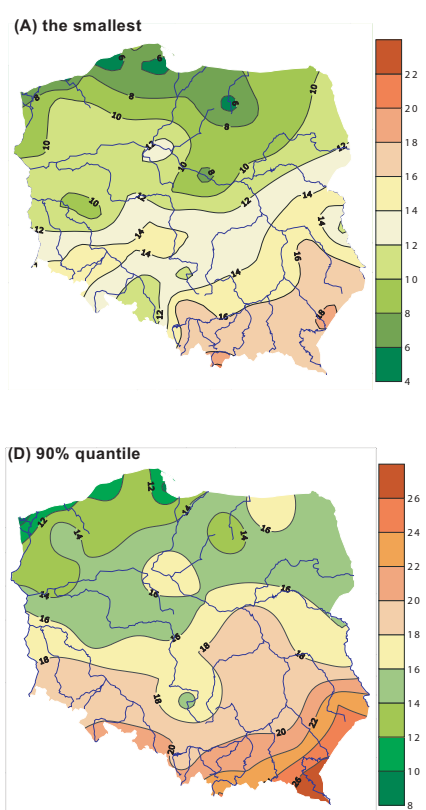
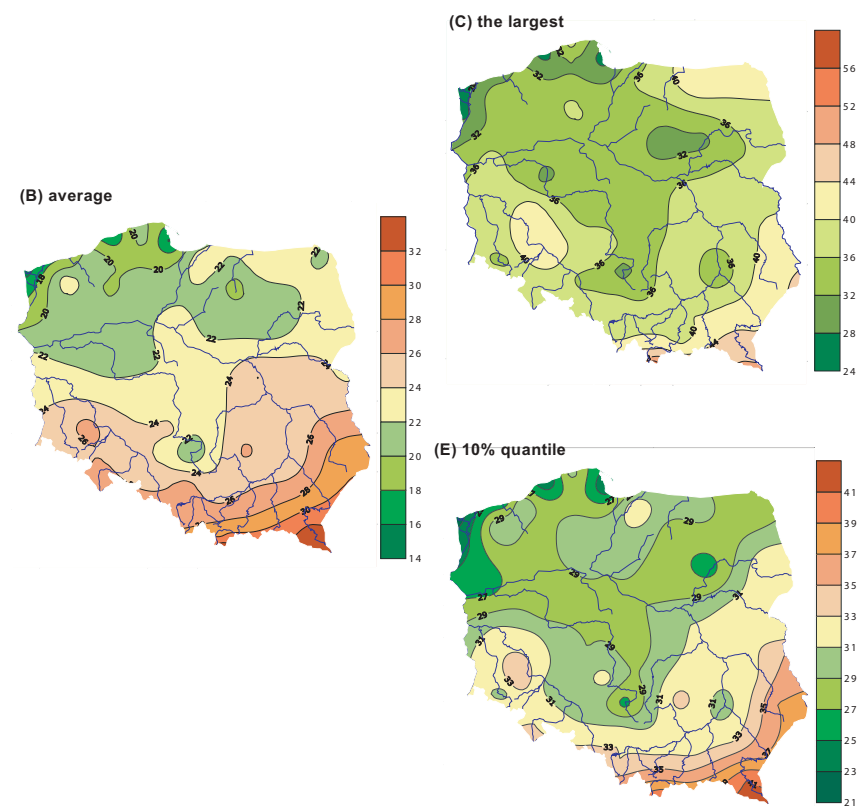

Figure 6. The number of days with thunderstorms in Poland in the period 1949-1998: the smallest (A), the average (B), the largest (C), the $90 \%$ quantile (D) and $10 \%$ quantile(E).

values by about $30-40 \%$ (36 stations) and in Suwałki, Leszno and Olsztyn it was almost twice as large.

The investigations on the long-term changeability of thunderstorms occurrence in Poland in the second half of the twentieth century revealed considerable differentiation even in the case of neighbouring stations (Fig 7). Apart from the station in Kielce and Włodawa, no clear trends in the thunder- storms occurrence (in the multi-annual period studied) were determined in annual, seasonal and monthly values. The only exception was a winter season, when a small increase in the frequency of thunderstorm occurrence at the end of the twentieth century was observed. It was also difficult to distinguish the periods in which the number of stormy days would be different from the average (at the statistically significant level), both in individual stations 

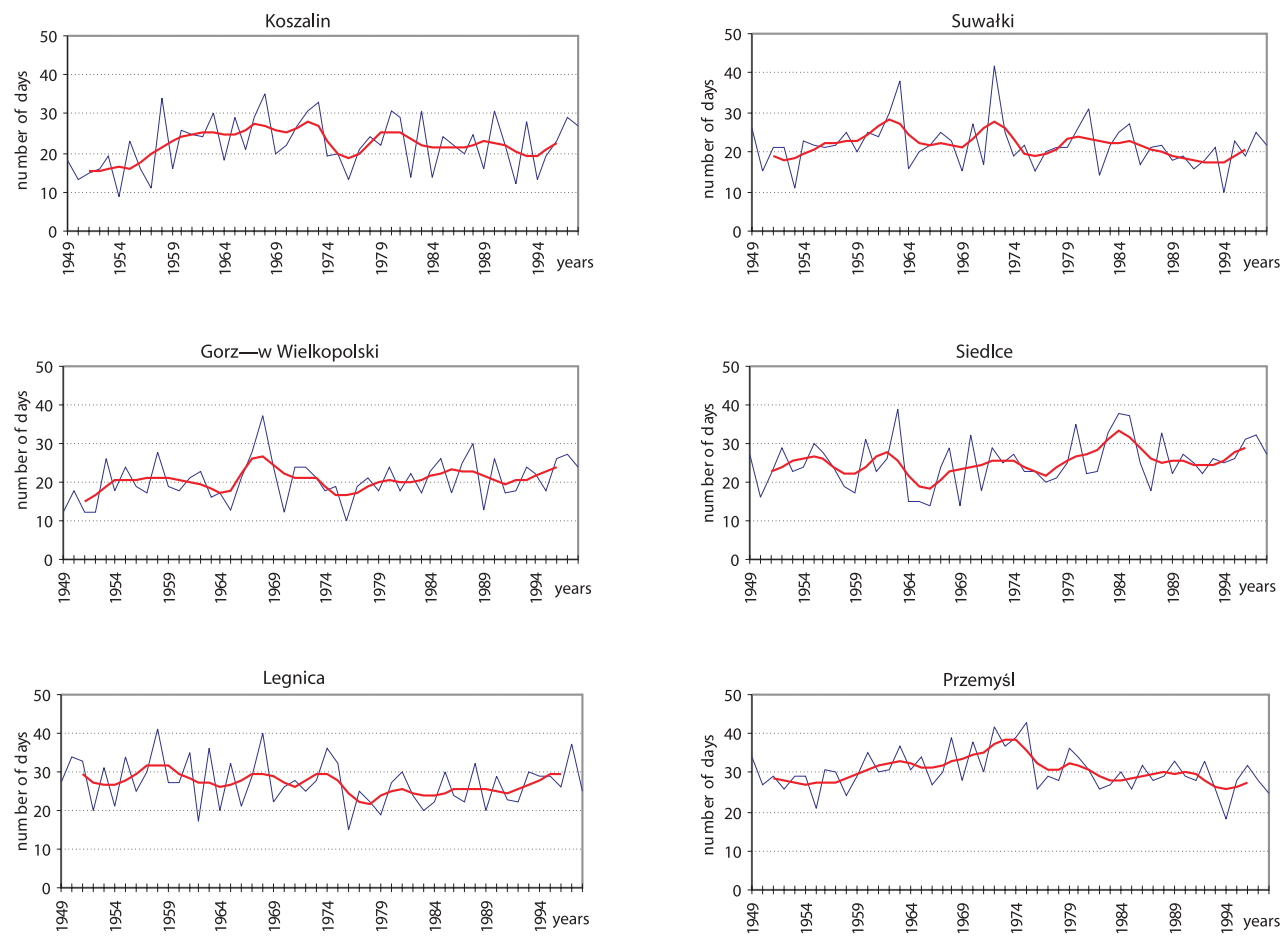

Figure 7 The number of days with thunderstorms at selected stations in Poland in the period 1949-1998. number of days values smoothed by 5 -element Gauss filter

and regions. Only the analysis of the changeability of the occurrence of thunderstorms in the established thunderstorm regions made it possible to observe a weak decrease in the mean number of stormy days in the western regions and their weak increase in the eastern regions (Bielec-Bakowska 2002).

The results described above have become the basis for investigating long-term changes in thunderstorm occurrence over the course of the twentieth century. The analysis was based on the number of days with a thunderstorm from seven stations (Hel, Szczecin, Koszalin, Poznań, Wrocław, Racibórz, Kraków) from the period 1885-2000. The mean number of stormy days at individual stations did not differ considerably from the mean value of the period 1949-1998 (for regions where they were located). While analysing such a long series of data, it is also difficult to distinguish very clear trends in the number of days with a thunderstorm, whether one considers annu- al or seasonal values (Fig. 8). The directional regression coefficient, calculated for the annual number of days with a storm at Hel, Szczecin, Racibórz and Kraków did not exceed 0.04 (at the confidence level $>0.05$ ). In Poznań, Wrocław and Koszalin the number of stormy days showed a certain increasing trend, and the regression indices were 0.05 , 0.04 and 0.09 respectively (statistically significant at the level $0.01,0.05$ and 0.01 respectively). It is also worth noting that at the beginning of the long-term period the smallest number of days with a thunderstorm was observed, but the range of the variability was larger than in years that followed. In that time, several periods occurred showing a much larger or a much smaller number of days with a thunderstorm. On the other hand, in the final decades of the twentieth century, more thunderstorms were observed, but the changeability index was clearly smaller than at the beginning of the long period studied 


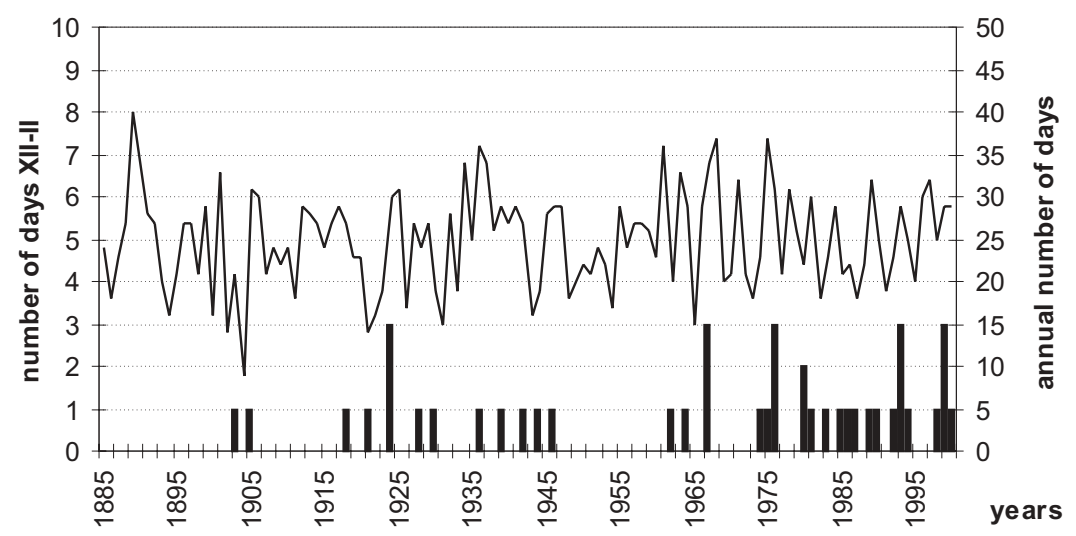

Figure 8 The number of days with thunderstorms in Kraków in the period 1885-2000. annual number of days

number of days in winter season (XII-II)

(Bielec-Bakowska, 2003). In the case of such long observation series, it was also visible that in the second half of the twentieth century, the increase in the number of stormy days in the winter months was not so clearly unambiguous and it concerned only Kraków, Szczecin and Koszalin. On the other hand, it was observed that after 1950 in Koszalin, Poznań, Wrocław and Kraków there was a small decrease in the number of stormy days from May to August, with a simultaneous increase in the occurrence of thunderstorms in the colder months of the year.

Changes in snow cover. In the period $1954 / 55-2000 / 01$ the seasonal maximum of the snow cover depth revealed a slight, though not statistically significant (at the 0.05 level) negative change of -1 to $-2 \mathrm{~cm}$ per 10 years in lowlands and up to $-8 \mathrm{~cm}$ per 10 years in the highest mountains (Table 4). The maximum seasonal snow cover depth of the empirical probability $10 \%$ varies in the nonmountainous area of Poland from $4 \mathrm{~cm}$ in the west to $5-10 \mathrm{~cm}$ in the central and coastal areas and $16 \mathrm{~cm}$ in the north-eastern part of the country (Fig. 9A). In the mountains, extremely thick snow cover is at most $15 \mathrm{~cm}$ in the foothills, $20-40 \mathrm{~cm}$ at Beskidy and about $100 \mathrm{~cm}$ on the highest summits $(91 \mathrm{~cm}$ at Śnieżka, $125 \mathrm{~cm}$ at Kasprowy Wierch). The snow cover depth of the empirical probability of $90 \%$ is the lowest in western Poland
(23 $\mathrm{cm}$ in Legnica) and increasing the further east and north-east, reaching at its maximum $50 \mathrm{~cm}$ (54 cm in Suwałki; Fig. 9B). Such a spatial distribution results from the effect of maritime air-masses coming off the Atlantic Ocean. In mountainous areas the probability of $90 \%$ corresponds to $40 \mathrm{~cm}$ of snow depth in the foothills, $40-100 \mathrm{~cm}$ at Beskidy and up to $300 \mathrm{~cm}$ on the highest summits $(211 \mathrm{~cm}$ at Śnieżka, $299 \mathrm{~cm}$ at Kasprowy Wierch). Thus, the mountain areas have the highest diversity in terms of extreme nival conditions.

The extremely thin snow cover (i.e. of the probability $<10 \%$ ) occurred in a large area of Poland in three periods; that is, at the end of the 1950s and the beginning of the 1960s, in the first half of the 1970s and since the middle of the 1980s (Fig. 10A). In the winter seasons of 1960/61 and 1974/75 the snow cover was extremely thin in the majority of the areas of Poland (i.e. in 33 and 37 of 60 meteorological stations respectively). On the other hand, in the 1960s and at the end of the 1970s and the beginning of the 1980s, extremely thin snow cover was hardly observed (only in particular regions). The years between 1961/62-1970/71 was the longest period during which extremely thin snow cover was observed in only $\leq 5 \%$ of the area of Poland. No significant trend was observed for the extremely thin snow cover area in Poland. 
Table 4. Change of the seasonal maximum snow cover depth (cm per 10 years) at the selected stations $(1954 / 55-2000 / 01)$. The trends are not statistically significant at the 0.05 level.

\begin{tabular}{|c|c|c|c|c|c|c|c|c|c|c|}
\hline station & 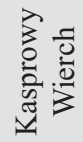 & 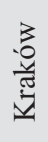 & t) & $\begin{array}{l}3 \\
0 \\
N \\
0 \\
\mathbb{N} \\
\simeq\end{array}$ & 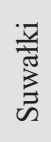 & 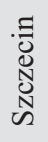 & 离 & $\frac{\pi}{3} \frac{\pi}{0}$ & $\begin{array}{l}3 \\
\frac{3}{8} \\
0 \\
0 \\
3\end{array}$ & 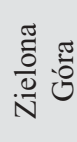 \\
\hline $\begin{array}{c}\text { change } / 10 \text { years } \\
{[\mathrm{mm}]}\end{array}$ & -8 & -2 & -1 & -2 & -1 & -2 & -1 & -2 & -1 & -2 \\
\hline
\end{tabular}
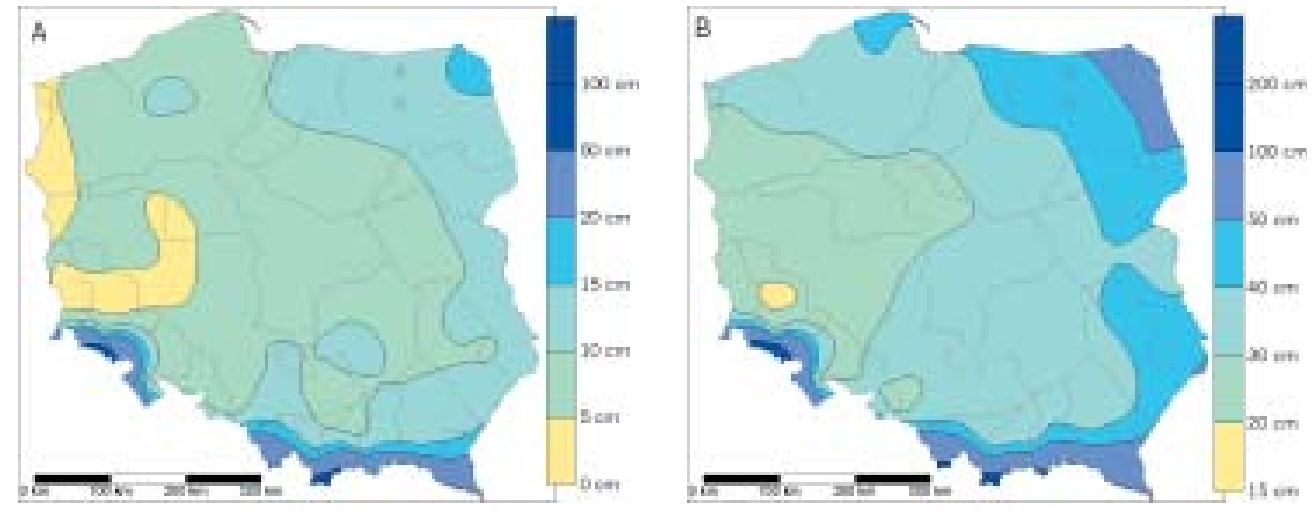

Figure 9. Seasonal maximum snow cover depth of the empirical probability A) $10 \%$, B) $90 \%$ (cm; $1954 / 55-2000 / 01)$.

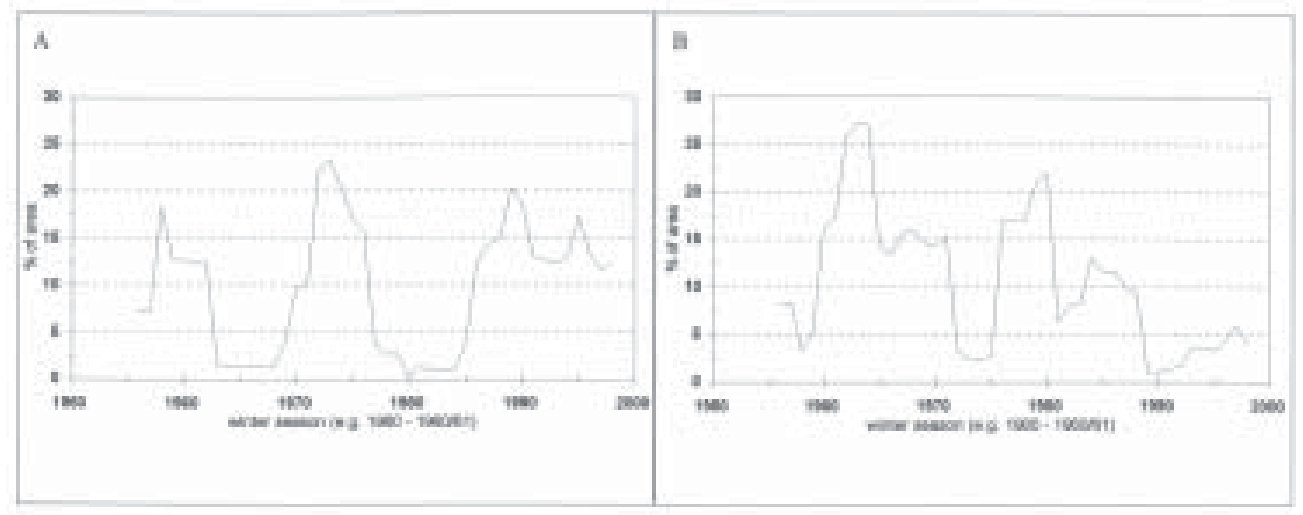

Figure 10. Percentage of Polish land area with the seasonal maximum snow cover depth of the empirical probability A) < 10\%, B) > 90\%: 5-year consecutive mean (\%; 1954/55-2000/01).

Extremely thick snow cover (i.e. of the probability $>90 \%$ ) was observed in a considerable part of the area of Poland in the first half of the $1960 \mathrm{~s}$, and at the end of the 1970 s and the beginning of the 1980s (Fig.
10B). In the winters $1962 / 63,1969 / 70$ and $1978 / 79$ very thick snow covered at least $60 \%$ of the area of the country $(78 \%$ in the last-mentioned winter). During the first half of the 1970 s and in the 1990 s extremely 
thick snow cover was not observed or was observed only in a small area. The years between 1987/88-1994/95 was the longest period during which extremely thick snow cover was observed in only $\leq 2 \%$ of the area of Poland. The area with extremely thick snow cover in Poland has not revealed a statistically significant trend.

\section{CONCLUSIONS}

The analysis of the long-term changeability of the selected characteristics of extreme meteorological events shows, in general, a lack of a clear trend in their long-term course. It means that in Poland until the end of the second half of the twentieth century, a statistically significant increase in the frequency of the occurrence of extreme precipitation as well as extremes concerning thunderstorm phenomena and snow cover was not observed.

A statistically significant tendency in the occurrence of extreme precipitation events in the second half of the twentieth century was not observed. Only a weak decreasing trend of the analysed indices of precipitation extremes was observed in the south-western part of Poland, and the opposite trend, but which was also of weak significance, was observed in northern Poland. Important changes concerning extreme precipitation in Poland occurred in the period that began in the mid-1960s and lasted until the early 1990s; however, they indicated a decrease of the indices studied. The long-term course of precipitation events in Poland showed relatively small spatial changeability in broad areas, especially in the central part of the country. The most important features of this course include: a higher than average number of days with extreme high precipitation in the 1960s and in 1979, a demonstrably lower frequency of the occurrence of such days in the 1950s, 1980s and at the beginning of the 1990s. Several regions that showed a similar long-term variability of extreme precipitation events can be distinguished. In the case of the analysed indices, four such areas were identified, and it should be emphasised that in mountain areas the long-term variability of the analysed extremes appeared to be considerably different than that of other regions. The preliminary investigations prove that a spatial configuration of the distinguished regions may be associated with the origin of the occurrence of this type of events.

The results concerning the occurrence of thunderstorms show that the tendencies relating to the number of days with a thunderstorm, both in the second half of the twentieth century and in longer periods, have not indicated any clear changes. It was difficult to determine periods that contained an increase in the number of stormy days, and to distinguish those regions that were characterized by similar long-term courses of the occurrence of this phenomenon. Only analysis of the long-term changeability of the average number of thunderstorms in selected stormy regions indicates their small increase in the eastern regions and a small decreasing trend in western Poland. When comparing the obtained results with the changeability of the occurrence of thunderstorms in the period $1885-2000$ at the selected stations, it was stated that no distinctive difference was observed in the frequency of the analysed phenomenon. Only in Poznań, Wrocław and Koszalin did the number of stormy days show a certain statistically significant increasing trend. The analysis of longer time series did not confirm an increasing tendency in the number of stormy days during the winter months, although it was explicitly determined in the second half of the twentieth century. It means that the discussed climate changes of the recent one hundred years have not had, to date, a considerable influence on the number of days with thunderstorms in Poland. The spatial differentiation in the occurrence of thunderstorms depends on local conditions, and changes to atmosphere circulation.

One of the main features of extreme snow cover events in Poland is their large year to year variability. There were not any significant trends either for the area of extremely thin or for extremely thick snow cover in Poland during the second half of the twenti- 
eth century. The fluctuations were especially noticeable in the case of extremely thin snow cover. One can note the repetition of similar features of that characteristic during every fifteen winter seasons. However, this regularity was somewhat disturbed in the last decade. Since the $1987 / 88$ winter, a considerable decrease of the area of extremely thin snow cover has not been observed. At the same time, the extent of extremely thick snow cover remained at a low level throughout the 1990s. The main reason for this situation seems to be the increasing frequency of the western air masses advection over Poland in the last decades of the twentieth century, which was found by T. Niedźwiedź (2000b). Therefore detailed analysis of extreme snow cover dependencies on the atmospheric circulation should be the next stage of the research programme.

\section{ACKNOWLEDGEMENTS}

The work was supported by the Polish Ministry of Education and Science under Grant PBZ-KBN-086/PO4/2003.

\section{REFERENCES}

Alexandersson, H. (1986), A homogeneity test applied to precipitation data, Journal of Climatology, 6: 661-675.

Bielec-Bakkowska, Z. (2002), Zróżnicowanie przestrzenne $i$ zmienność wieloletnia wystepowania burz w Polsce (1949-1998) [Spatial changeability and long-term variability of thunderstorms occurrence in Poland in the 1949-1998 period], Wydawnictwo Uniwersytetu Śląskiego, Katowice.

Bielec-Bąkowska, Z. (2003), Long-term variability of thunderstorms occurrence in Poland in the 20th century, Atmospheric Research, 67-68: 35-52.

Boryczka, J., Stopa-Boryczka, M. (eds.) (2002), Atlas wspólzależności parametrów meteorologicznych $i$ geograficznych $w$ Polsce, XVI. Prognozy zmian klimatu Polski [Atlas of the meteorologi- cal and geographical parameters interrelationships in Poland, XVI. Prediction of climate change in Poland], Wydawnictwo Uniwersytetu Warszawskiego, Warszawa, 164-205.

Brazdil, R. (1998), Casova a prostorova analiza bourek, krupobiti a extremnich srazek v jizni casti Moravy v obdobi 1946-1995 [Spatial and temporal analysis of thunderstorms, hailstorms and extreme precipitation in southern part of Moravia in the 1946-1995 period], Meteorologické zprávy, 51: 45-52.

Changnon, S. A. (1985), Secular variations in thunder-day frequencies in the Twentieth Century, Journal of Geophysical Research, 90, D4: 6181-6194.

Changnon, S. A. (1988), Climatography of thunder evens in the conterminous United States. Part I: Temporal aspects, Journal of Climate, 1: 389-398.

Changnon, S. A. (2001), Long-term fluctuations in thunderstorm activity in the United States, Climatic Change, 50: 489503.

Cebulak, E. (1992a), Maksymalne opady dobowe w dorzeczu górnej Wisły [Maximum daily precipitation in the upper Vistula basin], Zeszyty Naukowe UJ, Prace Geograficzne, 90: 79-96.

Cebulak, E. (1992b), Wpływ sytuacji synoptycznej na maksymalne opady dobowe w dorzeczu górnej Wisły [The influence of synoptic situation on maximum daily precipitation in the upper Vistula basin], Folia Geographica, series Geographica Physica, 23: 81-95.

Cebulak, E., Pyrc, R. (2006), Metody opracowania zdarzeń ekstremalnych na przyktadzie opadów atmosferycznych $o$ natężeniu $\geq 100 \mathrm{~mm} /$ dobe $w$ dorzeczu górnej Wisty w XX $i$ XXI [The methods of extreme events analysis based on the example of atmospheric precipitation of $\geq 100 \mathrm{~mm} /$ day intensity in the upper Vistula basine in the 20th and the 21st centuries], in Maciejewski, M., Ostojski, M (eds.), Zagrożenia środowiska naturalnymi zjawiskami ekstremalnymi [Environmental threats posed by natural extreme 
events], Instytut Meteorologii i Gospodarki Wodnej (IMGW), Warszawa, 9-26.

DeGaetano, A.T., Wilks, D. S. (1999), Mitigating snow-induced roof collapses using climate data and weather forecasts, Meteorological Applications, 4: 301-312.

Falarz, M. (2004), Variability and trends in the duration and depth of snow cover in Poland in the 20th century, International Journal of Climatology, 13: 1713-1727.

Falarz, M. (2007), Changes of extreme nival conditions in Poland during the second half of the 20th century, Meteorologische Zeitschrift, 17 (3): 339-344(6).

Gilbert, R.O. (1987), Statistical methods for environmental pollution monitoring, Van Nostrand Reinhold, New York.

Grabowska, K. (2002), Burze w Polsce i ich uwarunkowania (1951-1990) [Thunderstorms in Poland and their determinants (1951-1990)], Unpublished Ph. D. thesis, Archiwum Wydziału Geografii i Studiów Regionalnych, Uniwersytet Warszawski.

IPCC (2007), Summary for Policymakers, in Solomon, S., Qin, D., Manning, M., Chen, Z., Marquis, M., Averyt, K.B., Tignor, M. and Miller, H.L. (eds.), Climate Change 2007: The Physical Science Basis. Contribution of Working Group I to the Fourth Assessment Report of the Intergovernmental Panel on Climate Change, Cambridge University Press, Cambridge, United Kingdom and New York, NY, USA

Kirschenstein, M. (2006), Typy cyrkulacji $o$ ekstremalnych sumach opadów $w$ pótnocno-zachodniej Polsce [Circulation types of extreme precipitation totals in north-western Poland], in Maciejewski, M., Ostojski, M. (eds.), Zagrożenia środowiska naturalnymi zjawiskami ekstremalnymi, Instytut Meteorologii i Gospodarki Wodnej (IMGW), Warszawa, 130-145.

Klein Tank, A., Wijngaard, J., van Engelen, A. (2002), Climate of Europe: Assessment of observed daily temperature and precipitation extremes, KNMI, De Bilt, the Netherlands, 36, (available at $<$ www. knmi.nl/samenw/eca>).
Klein Tank, A. M. G., Können, G. P. (2003), Trends in indices of daily temperature and precipitation extremes in Europe, 1946-99, Journal of Climate, 16, 36653680.

Kossowska-Cezak, U., Mrugała, S. (1997), Wystepowanie okresów z opadami atmosferycznymi o anomalnej wysokości (na przykładzie Warszawy $i$ Lublina) [The occurrence of the anomalous precipitation periods (based on the examples of Warsaw and Lublin)], in Zieliński, J. (ed.) Ekstremalne zjawiska meteorologiczne, hydrologiczne i oceanograficzne [Extreme meteorological, hydrological and oceanographical events], Materials from the Jubilee Symposium of the Polish Geographical Society.

Kożuchowski, K. (2004), Zmienność opadów atmosferycznych $w$ Polsce $w$ XX $i$ XXI wieku [Variability of atmospheric precipitation in Poland in the 20th and 21th century], in Kożuchowski, K. (ed.), Skala, uwarunkowania i perspektywy wspótczesnych zmian klimatycznych $w$ Polsce [Scale, conditions and perspectives of the contemporary climatic changes in Poland], Wydawnictwo Biblioteka, Łódź 47-58.

Kożuchowski, K., Żmudzka, E. (2003), 100year series of area averaged temperatures and precipitation totals in Poland, Acta Universitatis Wratislaviensis No 2542, Studia Geograficzne, 75: 116-122.

Kuleshov, Y., de Hoedt, G., Wright, W., Brewster, A. (2002), Thunderstorm distribution and frequency in Australia, Australian Meteorological Magazine, 51: 145-154.

Niedźwiedź, T. (2000a), Dynamic to selected extreme climatic events in Poland, Geographia Polonica, 73, 2: 25-39.

Niedźwiedź, T. (2000b), Variability of the atmospheric circulation above Central Europe in the light of selected indices, Zeszyty Naukowe UJ, Prace Geograficzne, 107: 379-389.

Niedźwiedź, T., Michalczyk, Z., Starkel, L., Ustrnul, Z. (2006), Meteorological, hydrological and geomorphological extreme 
events in central Europe - an attempt of classification, in Jania, J., Kundzewicz, W. P. (eds.), Extreme hydrometeorological events in Poland and their impacts - European context, International Conference, Warsaw, Poland, 7-9 Dec. 2006, Book of Abstracts, 130-131.

Nosova, A. M. (1989), Mnogoletniye izmeneniya intensivnosti grozovoy deyatelnosti [Long-term variability in the intensity of thunderstorm activity], Meteorologia i Gidrologia, 3: 106-109.
Wibig, J. (2006), Daily precipitation totals variability in Poland (1951-2000), in Jania, J., Kundzewicz, W. P. (eds.), Extreme hydrometeorological events in Poland and their impacts - European context, International Conference, Warsaw, Poland, 7-9 Dec. 2006, Book of Abstracts, 86-89.

Paper first received: May 2007 In final form: May 2008 